\title{
Pesticide accumulations in water and sediment of dam lakes located in Thrace part of Marmara Region (Turkey)
}

\section{Cem Tokatlı}

Cite this article as:

Tokatl1, C. (2020). Pesticide accumulations in water and sediment of dam lakes located in Thrace part of Marmara Region (Turkey). Aquatic Research, 3(3), 124-134. https://doi.org/10.3153/AR20011

Trakya University, Ipsala Vocational School, Department of Laboratory Technology, Edirne, Turkey

ORCID IDs of the author(s): C.T. 0000-0003-2080-7920

\section{Submitted: 04.01 .2020}

Revision requested: 10.02 .2020

Last revision received: 18.03 .2020

Accepted: 27.03 .2020

Published online: 25.04 .2020

Correspondence:

Cem TOKATLI

E-mail: tokatlicem $@$ gmail.com

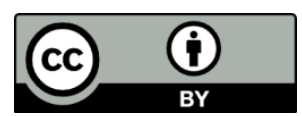

(C)Copyright 2020 by ScientificWebJournals Available online at

http://aquatres.scientificwebjournals.com

\begin{abstract}
Ergene River Basin, which is located in the north-west part of Turkey, is the most significant aquatic habitat of Thrace Region. In addition to the presence of important lentic ecosystems in the basin, there are also important natural and artificial lotic ecosystems, which are of great importance both for the natural life and for the local public. Thrace Region is one of the most important and fertile agricultural regions of our country and despite such a great importance of Ergene River Basin for Thrace Region, almost all the components of the watershed are being exposed to an intensive pollution by means of especially agricultural applications. In this research, the pesticide concentrations in water - sediment of most significant 6 dam lakes (Altınyazı, Karaidemir, Kayalıköy, Kırklareli, Sultanköy and Süloğlu Dam Lakes) located in Ergene River Basin were investigated. Water - sediment samples were taken in rainy season (spring) of 2018 from 15 stations and pesticide concentrations (174 pesticides varieties) were determined by using an LC/MS. In addition, the investigated locations were classified in terms of pesticide accumulations in water and sediment by using Cluster Analysis (CA). As a result of this research, 3 pesticide types in water and 18 pesticide types in sediment were detected. Carbendazim and forchlorfenuron-706 were recorded as the most dominant pesticide types for water samples and propiconazole and prochloraz were recorded as the most dominant pesticide types for sediment samples. The total pesticide contents determined in both water and sediment were found to be much higher in Altınyazı and Sultanköy Dam Lakes compared to the other investigated reservoirs. As a result of CA, 3 statistically significant clusters were formed both for water and sediment, which were named as "high contaminated zones", "low contaminated zones" and "moderate contaminated zones".
\end{abstract}

Keywords: Thrace Region, Dam Lakes, Water - Sediment quality, Pesticides, Cluster Analysis 


\section{Introduction}

Pesticides, which have become an integral part of the society, are widespread chemical compounds. They are used to increase the agricultural production in order to kill the pests including insects, rodents, fungi and weeds, which are damaging the agricultural crops. However, it is clearly known that, pesticides, which have long persistence in the environment, are potentially toxic to other organisms and dangerous for environment health, even at very low concentrations. Pesticides also tend to bio-accumulate and bio-magnify and are transferred to higher trophic levels through several food chains. As a result of this bio-magnification they may lead to toxicity in non-target organism and even in humans. Therefore, they need to be used safely and disposed of properly (Chopra et al. 2010, Ogbeide et al. 2015, Ccanccapa et al. 2016).

Ergene River Basin is the most significant river ecosystem of the Thrace Region and it is known to be exposed to a great agricultural and industrial pressure (Tokatl 12015, 2017; Tokatlı and Baştatlı 2016). Altınyazı, Karaidemir, Kayalıköy, Kırklareli, Sultanköy and Süloğlu Dam Lakes were constructed by DSI, on the Basamaklar, Poğaça, Teke, Şeytandere, Manastır and Süloğlu Streams respectively (DSİ, 2020). These reservoirs, which are located on the Ergene River Basin, are the most significant artificial lentic ecosystems of Thrace Region. As many freshwater ecosystems, these reservoirs are being adversely effected from agricultural and domestic pressure.

The main objective of this study was to determine the residues of 174 kinds of pesticides in the water and sediment samples of the most significant dam lakes located in the Thrace Region of Turkey.

\section{Material and Methods}

\section{Study Area and Collection of Samples}

Water and sediment samples were collected from 15 stations selected on the dam lakes in rainy (spring) season of 2018, when the precipitation and surface runoff have increased significantly in the basin. Altınyazı, Karaidemir, Kayalıköy, Kırklareli, Sultanköy and Süloğlu Dam Lakes and selected stations on the reservoirs are given in Figure 1.

Samples of water were collected 0.5 meter below the water surface in 1 liter precleaned bottles and they were kept at $4^{\circ} \mathrm{C}$ until the analysis. Samples of sediments were collected from the upper 10 centimeter of sediments by using an Ekman Grab in 1 liter sterile bottles and they were kept in dark and at $4^{\circ} \mathrm{C}$ until the analysis.

\section{Pesticide Analysis}

QUECHERS (Quick, Easy, Cheap, Effective, Rugged, Safe) method has been applied for determination of pesticide residues in water - sediment samples (Schenck and Hobbs 2004). Chemical analysis were made by using a ZIVAK TANDEM GOLD LC-MS / MS device with detection limit of $10 \mathrm{ppt}$. Samples were analysed in Trakya University Technology Research and Development Application Center, which has an international accreditation certificate within the scope of TS EN / ISO IEC 17025 issued by TÜRKAK (representative of the World Accreditation Authority in Turkey). All the element analyses were recorded by means of triplicate measurements.

Firstly, the samples were washed 3 times with distilled water and grinded in stainless steel blenders and made homogeneous. Other repeats of the same sample were also treated separately. 10 grams of analysis samples were weighed from these samples, and $100 \mathrm{~mL}$ of acetonitrile was added to it and it was broken down in the homogenizer. These samples, which will be homogenized by disintegration and placed in $50 \mathrm{~mL}$ balcony tubes, were centrifuged at $4000 \mathrm{rpm}$ for 10 minutes. After taking $50 \mathrm{~mL}$ from the upper phase of the samples, Cleanert MAS - Q (NaAc: 1.5 gr, $\mathrm{MgSO}_{4}: 6$ gr) kit was added to the new falt tubes for the cleaning stage and shaken for 1 minute. Samples were centrifuged again at $4000 \mathrm{rpm}$ for 30 minutes. Then, the upper phase is filtered through a PTFE filter with a pore diameter of $0.22 \mu \mathrm{m}$ and transferred to the vials and injected into the LC - MS / MS device (Schenck and Hobbs 2004).

In addition, solutions of $25,37.5,50,75,100,150,200 \mathrm{ppb}$ concentrations were prepared by diluting $100 \mu \mathrm{g} / \mathrm{mL}$ stock solutions in order to create calibration curves of pesticide standards. Calibration curves were drawn by analysing the prepared standard solutions. According to the quality control procedures, parameters such as laboratory and field blanks, matrix spikes were evaluated. The reliability of the sample preparation and calibration method was evaluated on the spiked samples. The calibrated midpoints $(10,000 \mathrm{ppt})$ were spiked by using pesticide-free water, and then the QUECHERS stages were applied. According to the result of the analysis, the recoveries were determined between the rates of $80-120 \%$. The list of pesticides investigated in the present research are given in Table 1. 


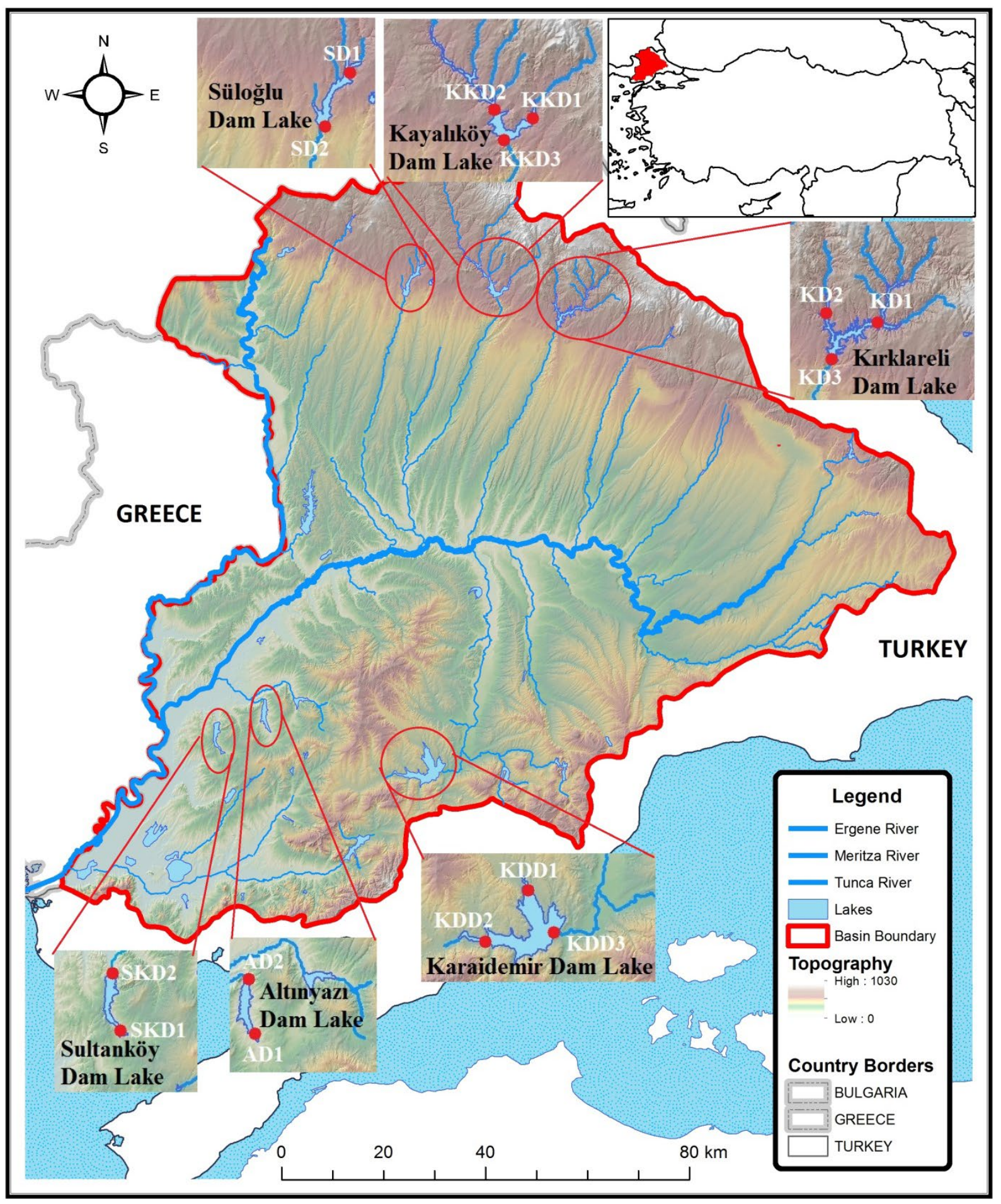

Figure 1. Study area and selected stations on the reservoirs 
Table 1. Names of investigated pesticides

\begin{tabular}{|c|c|c|c|}
\hline Acephate & Dimethoate & Ipconazole-713 & Prothioconazole -734 \\
\hline Acetamiprid & Dimoxystrobin-688 & Iprovalicarb & Pymetrozine \\
\hline Aldicarb & Diniconazole & Isoprocarb & Pyracarbolid \\
\hline Aldicarb sulfone & Dinotefuran & Isoproturon & Pyraclostrobin \\
\hline Aldicarb sulfoxide & Diuron & Kresoxim-methyl & Pyridaben \\
\hline Ametryne & Emamectin-Benzoate & Linuron & Pyrimethanil \\
\hline Aminocarb & Epoxiconazole & Mandopropamid & Pyriproxyfen \\
\hline Amitraz & Etaconazole & Mefenacet & Quinoxyfen \\
\hline Azoxystrobin & Ethiofencarb & Mepronil & Rotenone-739 \\
\hline Benalaxyl-M & Ethirimol & Metalaxyl & Secbumeton \\
\hline Bendiocarb & Ethofumasate & Metconazole -718 & Siduron \\
\hline Benfurocarb & Etoxazole & Methabenzthiazuron-719 & Simetryn \\
\hline Benzoximate & Famoxadone & Methamidophos & Spinetoram-741 \\
\hline Bifenazate & Fenamidone & Methiocarb & Spinosad A \\
\hline Bitertanol & Fenarimol & Methoprotryne & Spirodiclofen \\
\hline Boscalid & Fenazaquin & Methoxifenozide & Spiromesifen \\
\hline Bromuconazole & Fenbuconazole & Metobromuron & Spirotetramat \\
\hline Bupirimate & Fenhexamid & Metribuzin & Spiroxamine \\
\hline Buprofezin & Fenobucarb & Mevinphos & Tebuconazole \\
\hline Butocarboxim & Fenproprimorph & Mexacarbate & Tebufenozide \\
\hline Butoxycarboxim & Fenuron & Monocrotophos & Tebufenpyrad \\
\hline Carbaryl & Fibronil & Monolinuron & Tebuthiuron \\
\hline Carbendazim & Fluazinam & Myclobutanil & Terbumeton \\
\hline Carbetamide & Flubendiamide -695 & Neburon & Terbutryn \\
\hline Carbofuran & Fludioxonil & Nuarimol & Tetraconazole \\
\hline Carbofuran-3-hydroxy & Flufenacet & Omethoate & Thiabendazole \\
\hline Carboxin & Flufenoxuron & Oxadixyl & Thiacloprid \\
\hline Carfentrazone Ethyl & Fluometuron & Oxamyl & Thiamethoxam \\
\hline Chlorfluazuron & Fluoxastrobin-698 & Paclobutrazol & Thidiazuron-747 \\
\hline Chlorotoluron & Fluquinconazole -699 & Penconazole & Thiobencarb-748 \\
\hline Chloroxuron & Flusilazole & Pencycuron & Thiofanox \\
\hline Clethodim -682 & Flutolanil-703 & Phenmedipham & Thiophonate Methyl \\
\hline Clofentezine & Flutriafol & Picoxystrobin & Triadimefon \\
\hline Clothianidin & Forchlorfenuron-706 & Piperonyl butoxide & Triadimenol \\
\hline Cyazofamid & Formetanate-hydrochloride & Pirimicarb & Trichlorfon \\
\hline Cycluron & Fuberidazole-707 & Prochloraz & Tricyclazole-753 \\
\hline Cyproconazole & Furalaxyl & Promecarb & Trifloxystrobin \\
\hline Cyprodinil & Furathiocarb & Prometon & Triflumizole \\
\hline Cyromazine & Hexaconazole & Prometryn & Triflumuron \\
\hline Desmedipham & Hexaflumuron & Propamocarb-hydrochloride & Triticonazole \\
\hline Dicrotophos & Hexythiazox & Propargite & Vamidathion \\
\hline Diethofencarb & Hydramethylnon & Propham & Zoxamide \\
\hline Difenoconazol & Imazalil & Propiconazole & \\
\hline Diflubenzuron & Indoxacarb & Propoxur & \\
\hline
\end{tabular}




\section{Statistical Analysis}

"PAST" package statistical program was used for applying Cluster Analysis (according to Bray Curtis) to detected chemical data in water and sediment samples in order to classify the investigated dam lakes and selected stations on the reservoirs according to similar water - sediment quality characteristics.

\section{Results and Discussion}

According to detected data, among the investigated 174 kinds of pesticides, 3 kinds of pesticides residues were observed in water samples (Acetamiprid, Carbendazim and Forchlorfenuron-706) and 18 kinds of pesticide residues were observed in sediment samples (Acetamiprid, Azoxystrobin, Carbendazim, Cyproconazole, Difenoconazol, Dinotefuran, Epoxiconazole, Fluquinconazole -699, Imazalil, Metalaxyl, Picoxystrobin, Prochloraz, Propiconazole, Prothioconazole 734, Pyraclostrobin, Tebuconazole, Thiacloprid and Thiamethoxam). The mean values of pesticide concentrations are given in Table 2 and 3. The proportional values of pesticides for all the investigated reservoirs and the mean values of the total pesticide loads are given in Figure 2.

Table 2. Mean pesticide accumulations in waters of reservoirs ( $\mathrm{ppb}$ )

\begin{tabular}{|c|c|c|c|c|c|c|c|}
\hline Reservoir & Station & Pesticide & Residue & Reservoir & Station & Pesticide & Residue \\
\hline \multirow{6}{*}{$\begin{array}{l}\text { Kırklareli } \\
\text { Dam Lake }\end{array}$} & \multirow{2}{*}{ KD1 } & Carbendazim & 0.14 & \multirow{5}{*}{$\begin{array}{l}\text { Kayalıköy } \\
\text { Dam Lake }\end{array}$} & KKD1 & Carbendazim & 0.12 \\
\hline & & Forchlorfenuron-706 & 0.26 & & \multirow{2}{*}{ KKD2 } & Carbendazim & 0.23 \\
\hline & \multirow{2}{*}{$\mathrm{KD} 2$} & Carbendazim & 0.20 & & & Forchlorfenuron-706 & 0.55 \\
\hline & & Forchlorfenuron-706 & 0.41 & & \multirow{2}{*}{ KKD3 } & Carbendazim & 0.66 \\
\hline & \multirow{2}{*}{ KD3 } & Carbendazim & 0.15 & & & Forchlorfenuron-706 & 0.45 \\
\hline & & Forchlorfenuron-706 & 0.25 & \multirow{4}{*}{$\begin{array}{c}\text { Süloğlu } \\
\text { Dam Lake }\end{array}$} & \multirow{2}{*}{ SD1 } & Carbendazim & 0.15 \\
\hline \multirow{6}{*}{$\begin{array}{l}\text { Sultanköy } \\
\text { Dam Lake }\end{array}$} & \multirow{3}{*}{ SKD1 } & Carbendazim & 0.30 & & & Forchlorfenuron-706 & 0.26 \\
\hline & & Acetamiprid & 0.02 & & \multirow{2}{*}{$\mathrm{SD} 2$} & Carbendazim & 0.29 \\
\hline & & Forchlorfenuron-706 & 0.30 & & & Forchlorfenuron-706 & 0.23 \\
\hline & \multirow{3}{*}{ SKD2 } & Carbendazim & 0.40 & \multirow{6}{*}{$\begin{array}{c}\text { Karaidem } \\
\text { ir } \\
\text { Dam Lake }\end{array}$} & \multirow{2}{*}{ KDD1 } & Carbendazim & 0.12 \\
\hline & & Acetamiprid & 0.03 & & & Forchlorfenuron-706 & 0.40 \\
\hline & & Forchlorfenuron-706 & 0.43 & & \multirow{2}{*}{ KDD2 } & Carbendazim & 0.31 \\
\hline \multirow{3}{*}{$\begin{array}{l}\text { Altinyazı } \\
\text { Dam Lake }\end{array}$} & \multirow{2}{*}{$\mathrm{AD} 1$} & Carbendazim & 0.58 & & & Forchlorfenuron-706 & 0.68 \\
\hline & & Forchlorfenuron-706 & 0.83 & & \multirow{2}{*}{ KDD3 } & Carbendazim & 0.13 \\
\hline & $\mathrm{AD} 2$ & Carbendazim & 0.05 & & & Forchlorfenuron-706 & 0.22 \\
\hline
\end{tabular}


Table 3. Mean pesticide accumulations in sediment of reservoirs (ppb)

\begin{tabular}{|c|c|c|c|c|c|c|c|}
\hline Reservoir & Station & Pesticide & Residue & Reservoir & Station & Pesticide & Residue \\
\hline \multirow{25}{*}{$\begin{array}{c}\text { Karaidemir } \\
\text { Dam Lake }\end{array}$} & \multirow{7}{*}{ KDD1 } & Carbendazim & 4.97 & \multirow{18}{*}{$\begin{array}{c}\text { Altınyazı } \\
\text { Dam } \\
\text { Lake }\end{array}$} & \multirow{6}{*}{$\mathrm{AD} 1$} & Carbendazim & 0.02 \\
\hline & & Acetamiprid & 0.05 & & & Imazalil & 7.58 \\
\hline & & Azoxystrobin & 1.43 & & & Azoxystrobin & 3.12 \\
\hline & & Epoxiconazole & 15.59 & & & Prochloraz & 8.02 \\
\hline & & Prochloraz & 15.00 & & & Tebuconazole & 2.40 \\
\hline & & Tebuconazole & 3.14 & & & Propiconazole & 2.25 \\
\hline & & Propiconazole & 2.15 & & \multirow{12}{*}{$\mathrm{AD} 2$} & Carbendazim & 5.68 \\
\hline & \multirow{11}{*}{ KDD2 } & Carbendazim & 0.90 & & & Thiamethoxam & 0.50 \\
\hline & & Acetamiprid & 0.09 & & & Acetamiprid & 1.54 \\
\hline & & Metalaxyl & 0.26 & & & Thiacloprid & 0.40 \\
\hline & & Azoxystrobin & 36.99 & & & Cyproconazole & 9.95 \\
\hline & & Epoxiconazole & 60.57 & & & Azoxystrobin & 56.14 \\
\hline & & Prochloraz & 393.91 & & & Epoxiconazole & 53.66 \\
\hline & & Tebuconazole & 69.11 & & & Tebuconazole & 288.49 \\
\hline & & Propiconazole & 30.65 & & & Prochloraz & 4633.08 \\
\hline & & Difenoconazol & 7.19 & & & Propiconazole & 49.04 \\
\hline & & Picoxystrobin & 1.65 & & & Difenoconazol & 136.82 \\
\hline & & Pyraclostrobin & 25.79 & & & Picoxystrobin & 9.76 \\
\hline & \multirow{7}{*}{ KDD3 } & Carbendazim & 1.23 & \multirow{17}{*}{$\begin{array}{c}\text { Sultanköy } \\
\text { Dam } \\
\text { Lake }\end{array}$} & \multirow{8}{*}{ SKD1 } & Carbendazim & 0.44 \\
\hline & & Acetamiprid & 0.14 & & & Acetamiprid & 0.63 \\
\hline & & Azoxystrobin & 17.24 & & & Imazalil & 5.79 \\
\hline & & Epoxiconazole & 3.38 & & & Azoxystrobin & 6.90 \\
\hline & & Prochloraz & 12.19 & & & Prochloraz & 202.90 \\
\hline & & Tebuconazole & 5.84 & & & Tebuconazole & 11.83 \\
\hline & & Propiconazole & 3.70 & & & Prothioconazole - 734 & 366.09 \\
\hline \multirow{8}{*}{$\begin{array}{c}\text { Süloğlu } \\
\text { Dam Lake }\end{array}$} & \multirow{4}{*}{ SD1 } & Carbendazim & 0.50 & & & Propiconazole & 362.54 \\
\hline & & Imazalil & 0.96 & & \multirow{9}{*}{ SKD2 } & Carbendazim & 0.14 \\
\hline & & Azoxystrobin & 4.40 & & & Acetamiprid & 0.10 \\
\hline & & Prochloraz & 13.76 & & & Imazalil & 5.08 \\
\hline & \multirow{4}{*}{ SD2 } & Carbendazim & 0.43 & & & Azoxystrobin & 4.52 \\
\hline & & Imazalil & 2.11 & & & Fluquinconazole -699 & 119.64 \\
\hline & & Azoxystrobin & 4.18 & & & Tebuconazole & 64.69 \\
\hline & & Prochloraz & 4.99 & & & Prochloraz & 1287.10 \\
\hline \multirow{14}{*}{$\begin{array}{l}\text { Kayalıköy } \\
\text { Dam Lake }\end{array}$} & \multirow{3}{*}{ KKD1 } & Carbendazim & 0.49 & & & Prothioconazole -734 & 196.76 \\
\hline & & Imazalil & 5.67 & & & Propiconazole & 195.43 \\
\hline & & Azoxystrobin & 3.00 & \multirow{12}{*}{$\begin{array}{c}\text { Kurklareli } \\
\text { Dam } \\
\text { Lake }\end{array}$} & \multirow{4}{*}{ KD1 } & Dinotefuran & 1.38 \\
\hline & \multirow{5}{*}{ KKD2 } & Carbendazim & 0.40 & & & Carbendazim & 0.45 \\
\hline & & Imazalil & 8.00 & & & Imazalil & 5.24 \\
\hline & & Azoxystrobin & 3.48 & & & Azoxystrobin & 3.85 \\
\hline & & Prochloraz & 34.85 & & \multirow{4}{*}{$\mathrm{KD} 2$} & Dinotefuran & 1.05 \\
\hline & & Propiconazole & 4.30 & & & Carbendazim & 0.56 \\
\hline & \multirow{6}{*}{ KKD3 } & Carbendazim & 0.92 & & & Imazalil & 18.48 \\
\hline & & Acetamiprid & 0.09 & & & Azoxystrobin & 4.91 \\
\hline & & Azoxystrobin & 7.53 & & \multirow{4}{*}{ KD3 } & Dinotefuran & 2.05 \\
\hline & & Prochloraz & 29.76 & & & Carbendazim & 0.38 \\
\hline & & Droniconozalo & & & & Imazalil & 21.93 \\
\hline & & Propiconazole & 4.46 & & & Azoxystrobin & 28.70 \\
\hline
\end{tabular}




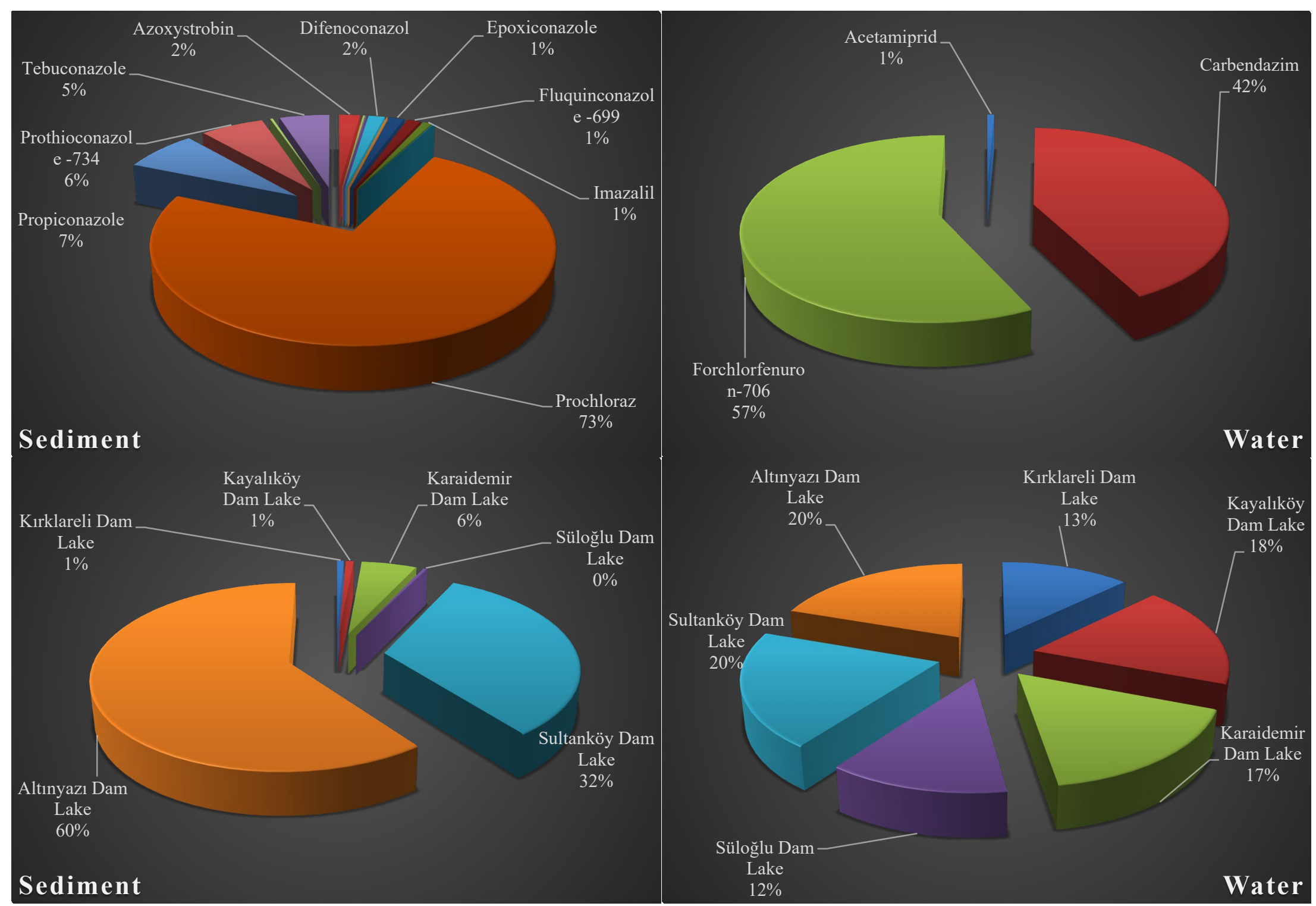

Figure 2. Pesticide rates (upside) and rates of total pesticide residues (downside) 
Cluster Analysis (CA), which is an unsupervised multivariate statistical technique, is used to classify the objects into clusters based on their similar characteristics (Belkhiri and Narany 2015, Tiri et al. 2017). In this investigation, CA was used to define the similar groups among the investigated locations according to accumulation levels of pesticides in water and sediment samples.

The diagrams of CA calculated by using pesticide concentration levels in water and sediment are given in Figure 3. According to the results of CA both for water and sediment, a total of 3 clusters were identified as "high contaminated zones", "moderate contaminated zones" and "low contaminated zones". In terms of recorded pesticide residues in water, higher risk cluster was formed by the stations of KKD2, KKD3, KDD2, SKD2 and AD1; moderate risk cluster was formed by the stations of SD1, SD2, SKD1, KD1, KD2, KD3, KDD1 and KDD3; lower risk cluster was formed by the stations of KKD1 and AD2. In terms of recorded pesticide residues in sediment, higher risk cluster was formed by the stations of KDD2, SKD1, SKD2 and AD2; moderate risk cluster was formed by the stations of KKD2, KKD3, SD1, SD2, $\mathrm{AD} 1, \mathrm{KDD} 1$ and KDD3; lower risk cluster was formed by the stations of KKD1, KD1, KD2 and KD3.

As a result of this study, it was determined that pesticide concentration levels recorded in the Altınyazı and Sultanköy Dam Lakes, which are located in the downstream of Ergene River Basin, were found to be in quite high levels. A total of 3 pesticide varieties were determined in water and a total of 18 pesticide varieties were determined in sediment. As a result of this research, forchlorfenuron-706 was found as the most common pesticide type in water samples and prochloraz was found as the most common pesticide type in sediment samples (Figure 2). Although the Forchlorfenuron-706 was found almost all the surface waters, it was not found in surface sediments. And although the prochloraz were found almost all the surface sediments, it was not found in surface waters. As it is clearly known that the waters are much more affected by instantaneous discharges, agricultural practices and precipitation than the sediments. Therefore, the sediments are used as a much more useful indicator than the waters in order to detect the long-term effects in aquatic ecosystems (Tokatl1, 2019; Ustaoğlu and Tepe, 2019; Ustaoğlu and Islam, 2020). Although the evaluation of waters is quite practical and widespread in especially periodic aquatic ecosystem assessment studies, use of the data determined in sediment samples in especially single season studies as in the present application is much more useful in terms of reflecting the effects of long-term contamination.

Pesticide contamination in water of reservoirs were found as Sultanköy $>$ Altınyazı $>$ Kırklareli $>$ Süloğlu $>$ Kayalıköy $>$ Karaidemir in terms of dam lakes and forchlorfenuron-706 $>$ carbendazim $>$ acetamiprid in terms of pesticide type. Pesticide contamination in sediment of reservoirs were found as Altınyazı $>$ Sultanköy $>$ Karaidemir $>$ Kayalıköy $>$ Kırklareli> Süloğlu in terms of dam lakes and prochloraz $>$ propiconazole $>$ prothioconazole-734 $>$ tebuconazole $>$ azoxystrobin $>$ difenoconazol $>$ epoxiconazole $>$ fluquinconazole-699 $>$ imazalil $>$ pyraclostrobin $>$ carbendazim $>$ picoxystrobin $>$ cyproconazole $>$ dinotefuran $>$ acetamiprid $>$ thiamethoxam $>$ thiacloprid $>$ metalaxyl in terms of pesticide type (Figure 2).
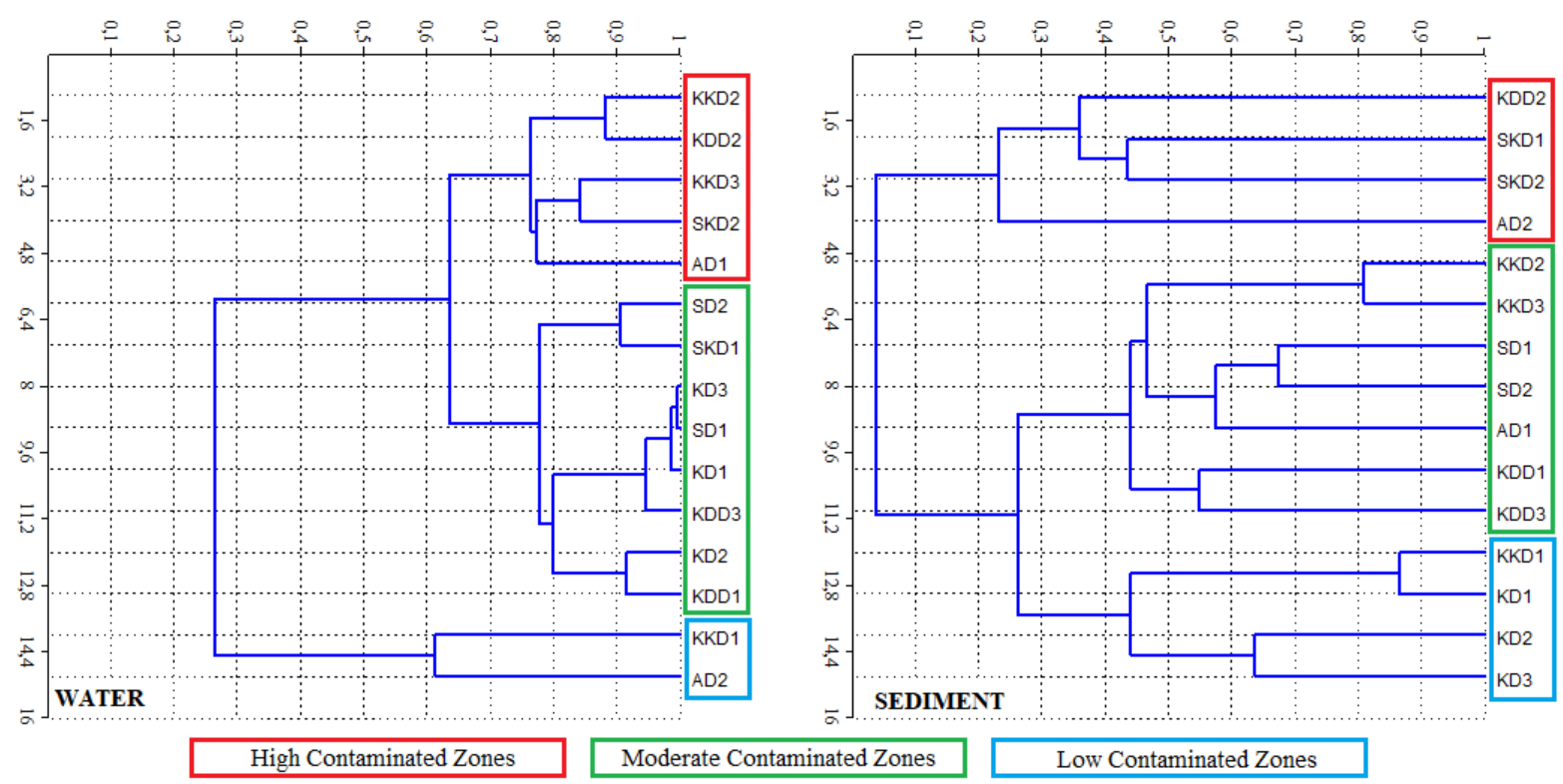

Figure 3. CA diagrams of investigated locations for water (left) and sediment (right) 
Although some stations were close to the limit value, it was determined that almost all the investigated stations in dam lakes of Ergene River Basin have I. Class water quality in terms of total pesticide concentrations (Turkish Regulations 2015). The investigated station of KKD1 (Kayalıöy Dam Lake), KDD2 (Karaidemir Dam Lake) and AD1 (Altınyazı Dam Lake) have II. Class water quality in terms of total pesticide concentrations (Turkish Regulations 2015). In a study performed in Thrace Region of Turkey, in contrast to the results of the present study, Meriç Delta was declared as low contaminated area in terms of organochlorine pesticide residues (Erkmen and Kolankaya 2006).

In a study performed in Thrace Region, pesticide accumulations in water and sediment of Meriç River Basin were investigated. According to the results of this research, as similar to the present study, carbendazim was found as the most dominant pesticide type for the system. And Meriç River Basin was declared as III. - IV. Class (polluted - high polluted) in terms of total pesticide accumulations in water (Tokatll et al., 2020). If we compare the present data with the results of this investigation, it can be clearly understood that the pesticide contamination levels of potamic habitats in Thrace Region are significantly higher than the artificial lacustrine habitats.

A number of studies conducted in different parts of the world, in different habitats and by different researchers have clearly revealed that, pesticides even in trace doses are significant contaminants for natural ecosystem and significant toxicants for all the biological organisms (Ogunfowokan et al. 2012, Masia et al. 2013, Wang et al. 2013). Agricultural activities carried out in the Ergene River Basin have been generally performed in the form of monoculture applications for many years. This situation causes the agricultural pests to have significant resistance gains over time and to increase the amount and quantity of pesticides used by the local producers every year. Especially in the Meriç - İpsala Plain, paddy farming has been going on without leaving fallow the soil and without changing the type of agricultural crop since about 1950-1960. In this study, the highest pesticide accumulations were determined in the Altınyazı and Süloğlu Dam Lakes, which are located on the downstream of Ergene River Basin and in the middle of Meriç - Ípsala Plain. This situation causes the agricultural pests to have significant resistance gains over time and to increase the amount and quantity of pesticides used by the local producers every year.

In a few socio-economic and socio-ecological studies conducted in the region, it has been revealed that the environmental sensitivity and environmental awareness of the local people is low and rice producers have performed paddy cultivation for many years (Tokatlı et al. 2013, Tokatlı and
Gürbüz 2014, 2015). In another socio-economic study conducted in the region, it has been revealed that many rice producers living in Edirne Province have performed paddy cultivation for more than 30 years (Helvacioğlu et al. 2015).

The detected data of this study clearly reveals the danger of monoculture agricultural applications around the region. It was also revealed that agricultural runoff is a major contamination source for all the artificial lentic components of the Ergene River Basin and overuse of pesticides may cause significant health problems not only for the ecosystem but also for the local people in the near future.

\section{Conclusions}

In this study, pesticide accumulations in water and sediment of Altınyazı, Karaidemir, Kayalıköy, Kırklareli, Sultanköy and Süloğlu Dam Lakes, which are located in the Ergene River Basin, were investigated. As a result of this study, agricultural pressure on the abiotic components of the reservoirs was clearly revealed. Altınyazı and Sultanköy Dam Lakes were found to be the most polluted ecosystems among the investigated artificial lentic habitats. Total pesticide contents of waters were found as Sultanköy $>$ Altınyazı $>$ Kırklareli $>$ Süloğlu $>$ Kayalıköy $>$ Karaidemir and total pesticide contents of sediments were found as Altınyazı $>$ Sultanköy $>$ Karaidemir $>$ Kayalıköy $>$ Kırklareli $>$ Süloğlu respectively. Forchlorfenuron-706 (in water) and prochloraz (in sediment) were found to be the most commonly used pesticide variety in the region. Although the reservoirs have I. - II. Class water quality in terms of total pesticide concentrations, in general, pesticide residues in sediments of investigated dam lakes were found to be in quite high levels. Also the applied CA was grouped 15 stations into 3 clusters of similar sediment quality characteristics; "high contaminated zones", "moderate contaminated zones" and "low contaminated zones" both for water and sediment. For the protection and improvement of the quality of these significant lentic ecosystems, monoculture agricultural practices should be changed and the farmers should be encouraged to polyculture applications. Also over use of fertilizers and pesticides should be prevented by providing environmental awareness for local people.

\section{Compliance with Ethical Standard}

Conflict of interests: The authors declare that for this article they have no actual, potential or perceived conflict of interests.

Ethics committee approval: All authors declare that this study does not include any experiments with human or animal subjects.

Funding disclosure: The present study was funded by the Trakya University, Commission of Scientific Research Projects (Project No. 2017/211).

Acknowledgments: - 


\section{References}

Ccanccapa, A., Masia, A., Navarro-Ortega, A., Pico, Y., Barcel, D. (2016). Pesticides in the Ebro River basin: Occurrence and risk assessment. Environmental Pollution, 211, 414-424.

https://doi.org/10.1016/j.envpol.2015.12.059

Chopra, A.K., Sharma, M.K., Chamoli, S. (2010). Bioaccumulation of organochlorine pesticides in aquatic systeman overview. Environmental Monitoring and Assessment, 173 , 905-916.

https://doi.org/10.1007/s10661-010-1433-4

Belkhiri, L., Narany, T.S. (2015). Using multivariate statistical analysis, geostatistical techniques and structural equation modeling to identify spatial variability of groundwater quality. Water Resources Management, 29(6), 2073-2089. https://doi.org/10.1007/s11269-015-0929-7

DSİ (2020). Baraj ve göletler. Devlet Su İşleri Genel Müdürlüğü, 11. Bölge Müdürlüğ̈̈-Edirne http://bolge11.dsi.gov.tr/isletmedekitesisler/baraj-veg\%C3\%B6letler (accessed 15.02.2020).

Erkmen, B., Kolankaya, D. (2006). Determination of organochlorine pesticide residues in water, sediment, and fish samples from the Meriç Delta, Turkey. International Journal of Environmental Analytical Chemistry, 86(1-2), 161-169.

Helvacioğlu, İ.A., Şener, T., Tokatlı, C., Balkan, A. (2015). Economic review of production possibilities and production costs of rice in "Ipsala - Karpuzlu - Meriç" region. 3rd International Conference on Agriculture \& Food, 1-5 June 2015, Elenite Holiday Village, Bulgaria, 193-201. https://doi.org/10.1080/03067310500247926

Masia, A., Ibanez, M., Blasco, C., Sancho, J.V., Pico, Y., Hernandez, F. (2013). Combined use of liquid chromatography triple quadrupole mass spectrometry and liquid chromatography quadrupole time-of-flight mass spectrometry in systematic screening of pesticides and other contaminants in water samples. Analytica Chimica Acta, 761, 117-127. https://doi.org/10.1016/j.aca.2012.11.032

Ogbeide, O., Tongo, I., Ezemonye, L. (2015). Risk assessment of agricultural pesticides in water, sediment, and fish from Owan River, Edo State, Nigeria. Environmental Monitoring and Assessment, 187, 654.

https://doi.org/10.1007/s10661-015-4840-8

Ogunfowokan, A.O., Oyekunle, J.A.O., Torto, N., Akanni, M.S. (2012). A study on persistent organochlorine pesticide residues in fish tissues and water from an agricultural fish pond. Emirates Journal of Food and Agriculture, 24(2), 165-184.

Schenck, F.J., Hobbs, J.E. (2004). Evaluation of the quick, easy, cheap, effective, rugged, and safe (QuEChERS) approach to pesticide residue analysis. Bulletin of Environmental Contamination and Toxicology, 73(1), 24-30. https://doi.org/10.1007/s00128-004-0388-y

Tiri, A., Lahbari, N., Boudoukha, A. (2017). Assessment of the quality of water by hierarchical cluster and variance analyses of the Koudiat Medouar Watershed, East Algeria. Applied Water Science, 7(8), 4197-4206.

https://doi.org/10.1007/s13201-014-0261-z

Tokatli, C. (2015). Assessment of the water quality in the Meriç River: As an element of the ecosystem in the Thrace Region of Turkey. Polish Journal of Environmental Studies, 24(5), 2205-2211.

https://doi.org/10.15244/pjoes/58780

Tokatli, C. (2017). Bio-Ecological and statistical risk assessment of toxic metals in sediments of a worldwide important wetland: Gala Lake National Park (Turkey). Archives of Environmental Protection, 43(1), 34-47.

https://doi.org/10.1515/aep-2017-0007

Tokatlı, C. (2019). Sediment quality of Ergene River Basin: Bio - Ecological risk assessment of toxic metals. Environmental Monitoring and Assessment, 191(11), 1-12.

https://doi.org/10.1007/s10661-019-7885-2

Tokatli, C., Baştatli, Y. (2016). Trace and toxic element levels in river sediments. Polish Journal of Environmental Studies, 25(4), 1715-1720.

https://doi.org/10.15244/pjoes/62678

Tokatli, C., Gürbüz, E. (2014). Socioeconomical and socioecological assessment on the perceptions of local people of 
the Enez and Yeni Karpuzlu Districts (Edirne) on the Gala Lake National Park. International Journal of Social and Economic Sciences, 4(2), 01-05.

Tokatlı, C., Gürbüz, E. (2015). Ethnicity and the environmental awareness: Romani of İpsala. International Journal of Social and Economic Sciences, 5(1), 09-14.

Tokatlı, C., Gürbüz, E., Arslan, N. (2013). Socio - Ecological and economical interactions between local public (Enez) with the Gala Lake National Park (Edirne, Turkey). UNITECH 2013, 22-23 November 2013, Gabrovo, Bulgaria, 383-386.

Tokatlı, C., Köse, E., Çiçek, A., Emiroğlu, Ö. (2020). Pesticide accumulation in Turkey's Meriç River basinwater and sediment. Polish Journal of Environmental Studies, 29(1), 16.

https://doi.org/10.15244/pjoes/101618

Turkish Regulations (2015). Yüzeysel su kalitesi yönetimi yönetmeliği. 15/04/2015 tarihli Resmi Gazete, Sayı: 29327, http://suyonetimiormansu.gov.tr (accessed 15.02.2020).

Ustaoğlu, F., İslam, S. (2020). Potential toxic elements in sediment of some rivers at Giresun, Northeast Turkey: A preliminary assessment for ecotoxicological status and health risk. Ecological Indicators, 113, 106237. https://doi.org/10.1016/j.ecolind.2020.106237

Ustaoğlu, F., Tepe, Y. (2019). water quality and sediment contamination assessment of Pazarsuyu Stream, Turkey using multivariate statistical methods and pollution indicators. International Soil and Water Conservation, 7, 47-56. https://doi.org/10.1016/j.iswcr.2018.09.001

Wang, L., Jia, H.L., Liu, X. J., Sun, Y.Q., Yang, M., Hong, W.J., Qi, H., Li, Y.F. (2013). Historical contamination and ecological risk of organochlorine pesticides in sediment core in northeastern Chinese river. Ecotoxicology and Environmental Safety, 93, 112-120.

https://doi.org/10.1016/j.ecoenv.2013.04.009 